\title{
Molecular identification of Trichinella species by multiplex PCR: new insight for Trichinella murrelli
}

\author{
Grégory Karadjian ${ }^{1, *}$, Aurélie Heckmann ${ }^{1}$, Giuseppe La Rosa ${ }^{2}$, Edoardo Pozio ${ }^{2}$, Pascal Boireau ${ }^{1}$, and \\ Isabelle Vallée ${ }^{1}$ \\ 1 JRU BIPAR, ANSES, École Nationale Vétérinaire d'Alfort, INRA, OIE Collaborating Centre for Foodborne Zoonotic \\ Parasites, Laboratory for Animal Health, 14 Rue Pierre et Marie Curie, 94701 Maisons-Alfort Cedex, France \\ 2 European Union Reference Laboratory for Parasites, Istituto Superiore di Sanità, Viale Regina Elena 299, 00161 Rome, Italy
}

Received 16 October 2017, Accepted 22 November 2017, Published online 8 December 2017

\begin{abstract}
In order to identify Trichinella at the species level, the commonly used test is a multiplex PCR, allowing the discrimination of nine out of the twelve taxa described so far. This test is based on five primer pairs amplifying fragments of the large subunit rDNA. Each taxon produces one or two bands of different sizes, resulting in a specific band pattern. By multiplex PCR, Trichinella murrelli shows two bands of $127 \mathrm{bp}$ and $316 \mathrm{bp}$. However, a third band of $256 \mathrm{bp}$ can occur. This band can lead to misidentification, since it is similar to the $253 \mathrm{bp}$ band displayed by Trichinella britovi. BLAST analysis confirmed that the $256 \mathrm{bp}$ band is from T. murrelli. The aim of this short note is to inform analysts that T. murrelli larvae may display either two- or three-band patterns.
\end{abstract}

Keywords: Trichinella murrelli, multiplex PCR, ITS1

Résumé - Identification moléculaire des espèces de Trichinella par PCR multiplex : nouvel éclairage pour Trichinella murrelli. Afin d'identifier les Trichinella au niveau de l'espèce, le test couramment utilisé est une PCR multiplex, permettant la discrimination de neuf des douze taxons décrits jusqu'à présent. Ce test est basé sur cinq paires d'amorces amplifiant des fragments de la grande sous-unité l'ADN ribosomal. Chaque taxon produit une ou deux bandes de tailles différentes, résultant en un patron de bandes spécifique. Par PCR multiplex, Trichinella murrelli présente deux bandes de $127 \mathrm{pb}$ et $316 \mathrm{pb}$. Cependant, une troisième bande de $256 \mathrm{pb}$ peut s'observer. Cette bande peut être la cause d'une erreur d'identification, car elle est similaire à la bande de 253 pb affichée par Trichinella britovi. L'analyse BLAST a confirmé que la bande à $256 \mathrm{pb}$ provient de T. murrelli. Le but de cette note est d'informer les analystes que les larves de T. murrelli peuvent présenter des patrons à deux ou trois bandes.

\section{Introduction}

Trichinella spp. are the causative agents of trichinellosis, a foodborne zoonotic disease acquired through the consumption of raw or undercooked meat infected by larvae in the muscle cells. The main sources of human infection are domestic pigs and wild boars [6,15]. Meat inspection of susceptible livestock (backyard and freeranging pigs, horses) at slaughterhouses and game at game handling establishments is an important measure for preventing human infection [8]. On a routine basis, this inspection is internationally regulated with direct detec-

\footnotetext{
*Corresponding author: gregory . karadjian@anses.fr
}

tion of larvae achieved through artificial digestion of infected muscle samples $[2,3,11,16,23]$. The isolation of Trichinella larvae from muscles of infected animals allows the removal of infected carcasses from the food chain and enables the identification of larvae at species or genotype level in order to acquire valuable epidemiological information to control these zoonotic pathogens [8,21]. To date, nine species and three genotypes have been recognized within the Trichinella genus [12]. Eight of these taxa have been proven to be infectious to humans, while the remaining four are considered as potentially infective to humans [21]. Species/genotypes within these taxa are morphologically indistinguishable (sibling species), and their identification relies on the use of biochemical or molecular assays $[14,20,24]$. 
Table 1. Multiplex PCR fragment sizes of the 12 taxa of the genus Trichinella.

\begin{tabular}{|c|c|c|c|c|c|c|c|c|c|c|}
\hline \multirow[t]{2}{*}{ Primer set } & \multirow[t]{2}{*}{ Locus $^{\mathrm{a}}$} & \multicolumn{9}{|c|}{ Trichinella taxon fragment size (bp) } \\
\hline & & Tsp & Tna/Tpat & $\mathrm{Tbr} / \mathrm{T} 8 / \mathrm{T} 9$ & Tps & $\mathrm{Tmu}$ & T6 & Tne & Tpa & Tzi \\
\hline I & ESV & 173 & 127 & 127 & $310-360$ & 127 & 127 & 155 & 240 & 264 \\
\hline II & ITS1 & & & 253 & & 256 & & & & \\
\hline III & ITS1 & & & & & & 210 & & & \\
\hline IV & ITS2 & & & & & 316 & & & & \\
\hline$\underline{\mathrm{V}}$ & ITS2 & & & & & & & 404 & & \\
\hline
\end{tabular}

Trichinella spiralis (Tsp), T. nativa (Tna), T. britovi (Tbr), T. pseudospiralis (Tps), T. murrelli (Tmu), T. nelsoni (Tne), T. papuae(Tpa), T. zimbabwenzis (Tzi), T. patagoniensis (Tpat) and Trichinella genotypes T6, T8 and T9. The size (bp) of the ITS1 fragment of T. murrelli is in bold. The fragment sizes are those from Zarlenga et al. (1999) [24], Pozio and La Rosa (2010) [20] and Krivokapich et al. (2012) [13].

a ESV, expansion segment V region of the ribosomal DNA repeat; ITS1 and ITS2, internal transcribed spacers 1 and 2.

The North American species Trichinella murrelli [17] is known to circulate freely among wild carnivore mammals in the United States [9,18,22] and Canada [7], however this zoonotic pathogen has also been documented in domestic dogs and horses $[4,10,19,21]$. Although T. murrelli has not been recorded in European wildlife, this pathogen was the causative agent of a severe human outbreak, which occurred through the consumption of raw horse-meat imported from Connecticut (USA) to France in $1985[1,5]$.

The most common molecular test for Trichinella taxon identification is a multiplex PCR analysis, which allows unequivocal identification of nine of the 12 recognized taxa on the basis of the generation of one- or two-band patterns [20]. This test is based on the use of five primer pairs amplifying the internal transcribed spacers ITS1 and ITS2 and the expansion segment V region(ESV) of the large subunit ribosomal DNA [24]. According to this method, T. murrelli shows a double-band pattern of $127 \mathrm{bp}$ and $316 \mathrm{bp}$.

In 2016, as part of proficiency testing to identify the species/genotype of Trichinella larvae, the National Reference Laboratories (NRLs) for Parasites in European Union member states reported a three-band pattern for T. murrelli larvae instead of the expected two-band pattern $[20,24]$. The aim of this work was to investigate whether the extra band belongs to T. murrelli or is a faint band caused by slightly modified protocols (Table 1).

\section{Materials and methods}

\section{Trichinella larvae}

Muscle larvae were collected from CD1 or OF-1 female mice infected by four T. murrelli isolates (codes ISS35, ISS246, ISS346, and ISS415; www.iss.it/Trichinella/), and by a T. britovi isolate (code ISS100) by HCl-pepsin digestion, according to a published protocol [3].

\section{DNA isolation}

The DNA was extracted using the DNA IQ System Kit (PROMEGA, DC6701) and the Tissue and Hair Extraction Kit (PROMEGA, DC6740) with a few modifications. Briefly, $20 \mu \mathrm{L}$ of incubation buffer with DTT and proteinase $\mathrm{K}$ were added to larvae and incubated at $55^{\circ} \mathrm{C}$ for $30 \mathrm{~min}$ shaking at 1,400 vibrations per min. Then, $40 \mu \mathrm{L}$ of lysis buffer with DTT and $4 \mu \mathrm{L}$ of paramagnetic

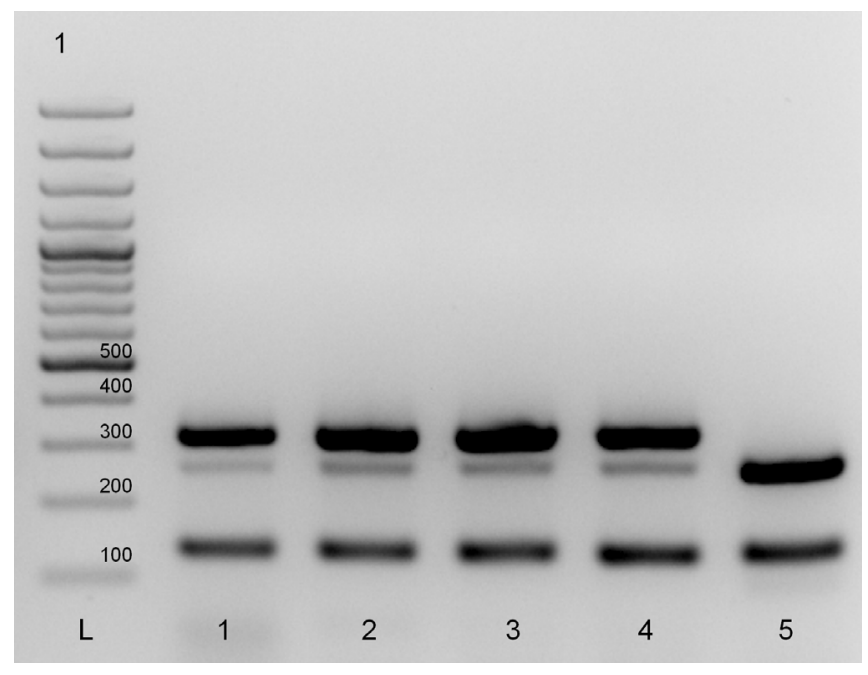

Figure 1. Electrophoretic profiles of Trichinella murrelli and T. britovi larva amplicons after multiplex PCR amplification.DNA extracts from 1 and 10 larvae of T. murrelli (isolate code ISS35) in lane 1 and lanes 2-4, respectively; and of T. britovi (isolate code ISS235) larva in lane 5 . Lane L1 $=100$ bp ladder.

resin were added. The entire solution was incubated at $25^{\circ} \mathrm{C}$ for $5 \mathrm{~min}$ in a thermoblock without vibration, with a single vortexing step performed at mid time. Tubes were then placed in a magnetic separation stand for $1 \mathrm{~min}$. The liquid phase was discarded. Then $100 \mu \mathrm{L}$ of lysis buffer were added and resin particles were re-suspended before tubes were replaced on a paramagnetic stand and the liquid phase removed. The samples were washed four times using $100 \mu \mathrm{L}$ washing buffer. The particles were then air-dried for $15 \mathrm{~min}$ and samples were eluted using $50^{\circ} \mu \mathrm{L}$ of elution buffer for 5 min at $65^{\circ} \mathrm{C}$ shaking at 1,400 vibrations per min.

\section{Multiplex and uniplex PCR}

Five primer pairs were used in a multiplex PCR as described by Zarlenga et al. (1999) [24] (Primer set I, ESV target locus, 5'-GTTCCATGTGAACAGCAGT-3', 5'CGAAAACATACGACAACTGC-3'; primer set II, ITS1 target locus, 5'-GCTACATCCTTTTGATCTGTT-3', 5'AGACACAATA TCAACCACAGTACA- $3^{\prime}$; primer set 


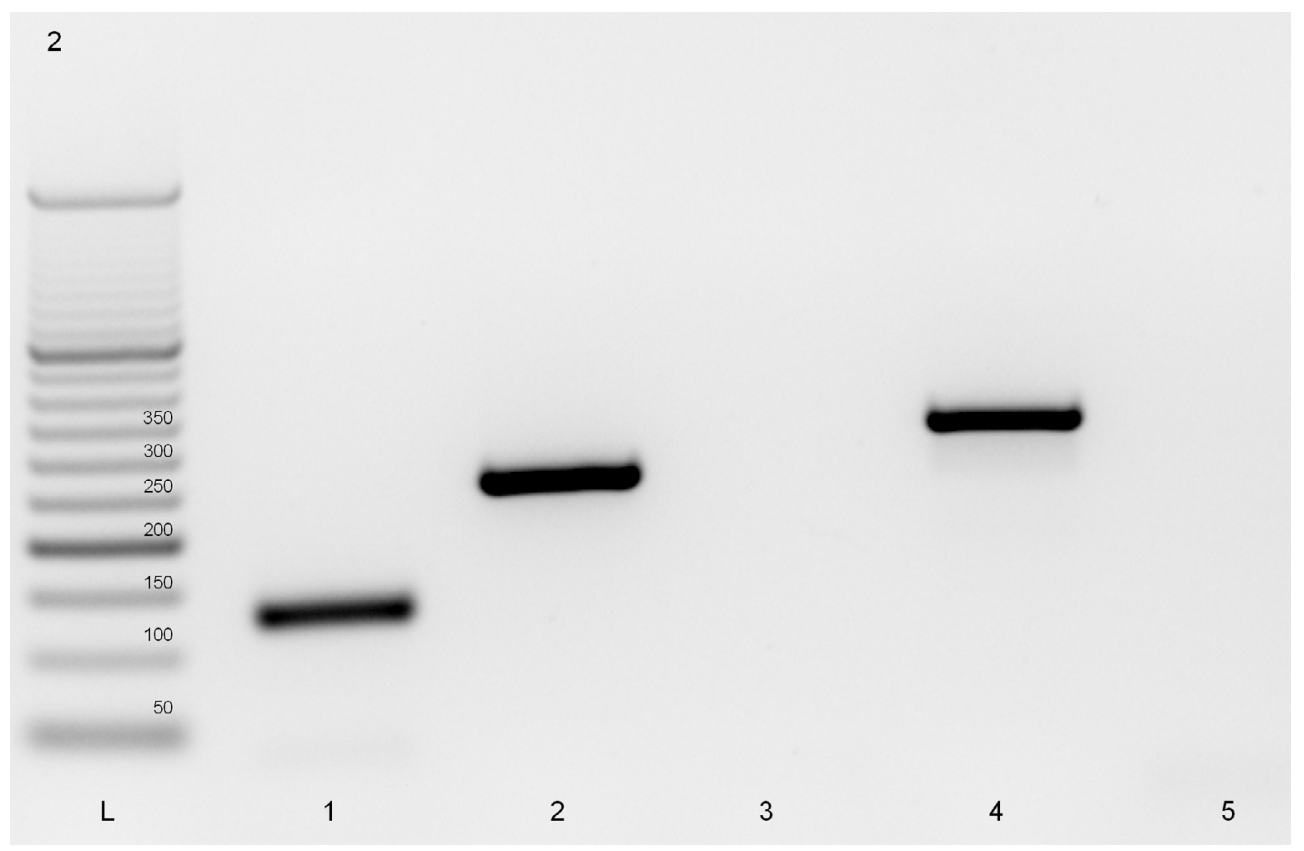

Figure 2. Electrophoretic profiles of Trichinella murrelli uniplex PCR amplifications.DNA from T. murrelli (isolate code ISS35) reference larvae was used. Lane $\mathrm{L}=50 \mathrm{bp}$ ladder. The genes targeted were the Expansion Segment V (ESV, lane 1), Internal Transcribed Spacer 1 II (ITS1 II, Lane 2), ITS1 III (lane 3), ITS2 IV (lane 4), and ITS2 V (lane 5).

III, ITS1 target locus 5'-GCGGAAGGATCATTATCGTGTA-3', 5'-TGGATTACAAAGAAAACCATCACT-3'; primer set IV, ITS2 target locus $5^{\prime}$ GTGAGCGTAATAAAGGTGCAG-3', , 5'-TTCATCACACATCTTCCACTA-3'; and primer set V, ITS2 target locus 5'-CAATTGAAAACCGCTTAGCGTGTTT- $3^{\prime}, 5^{\prime}$ TGATCTGAGGTCGACATTTCC- $3^{\prime}$. Reactions were performed in $15 \mu \mathrm{L}$ of $2 \mathrm{X}$ GoTaq ${ }^{\circledR}$ Hot Start Green MasterMix (PROMEGA, M5122), $9 \mu \mathrm{L}$ of nuclease free water, $1 \mu \mathrm{L}$ of total primers, and $5 \mu \mathrm{L}$ of extracted DNA.

The uniplex PCR was performed using the same mix as above but with only primer set II for the ITS1 locus at a final concentration of $10^{\circ} \mu \mathrm{M}$.

The PCR cycles for both multiplex and uniplex PCR were performed as follows: a pre-denaturation and polymerase activation step at $95^{\circ} \mathrm{C}$ for $2 \mathrm{~min}$, then 35 amplification cycles (denaturation at $95^{\circ} \mathrm{C}$ for $10 \mathrm{sec}$, hybridization at $55^{\circ} \mathrm{C}$ for $30 \mathrm{sec}$, and elongation at $72^{\circ} \mathrm{C}$ for $30 \mathrm{sec}$ ), and a final elongation step at $72{ }^{\circ} \mathrm{C}$ for $5 \mathrm{~min}$.

\section{Electrophoresis and sequencing}

Agarose (Ozyme, LON50004) gels (2\%) were prepared in TAE (2M Tris-acetate, 50 mM EDTA, pH 8.3) (Lonza, BE51216) solution with $5 \mathrm{ng} / \mathrm{mL}$ of ethidium bromide (Sigma, E1510). Electrophoresis was performed using $10 \mu \mathrm{L}$ of PCR products with a 50 bp O'Range Ruler DNA ladder (Fermentas, SM0613) for $30 \mathrm{~min}$ at $100 \mathrm{~V}$. PCR products were sequenced using the appropriate primers by Eurofins-MWG (Plateforme de l'Hôpital Cochin, Paris, France).

\section{Results and Discussion}

Following multiplex PCR amplification, T. murrelli larvae displayed two- or three-band patterns independently of the isolate and the laboratory where the test was performed. A three-band pattern of $127 \mathrm{bp}, 256 \mathrm{bp}$ and 316 bp was observed by the French NRL (Figure 1), whereas a two-band pattern (127 bp and $316 \mathrm{bp}$ ) or a three-band pattern (127 bp, $256 \mathrm{bp}$ and $316 \mathrm{bp}$ ) were found by the European Union Reference Laboratory for Parasites (EURLP) in Rome. Using the same multiplex PCR analysis protocol, T. britovi larvae displayed the expected band pattern of $127 \mathrm{bp}$ and $253 \mathrm{bp}$ (Figure 1).

Since the $256 \mathrm{bp}$ band produced by T.murrelli was unexpected, a uniplex PCR was performed to identify which couple of primers allowed the amplification of the extra band. The $256 \mathrm{bp}$ band amplified with primer pair II for ITS1 (Figure 2) was sequenced and identified by BLAST. The result revealed $99.6 \%$ identity with $T$. murrelli (GenBank accession number KC006421). Only one base was different and corresponded to the last base of the forward primer-annealing region (Figure 3). It follows that the complementarity of the forward primer is not $100 \%$ and this may explain the intermittent amplification of the $256 \mathrm{bp}$ product. Slightly different PCR conditions may affect annealing, resulting in two- or three-band patterns.

The appearance of a third unexpected band using DNA of T. murrelli larvae by the multiplex PCR analysis described by Zarlenga et al., (1999) [24] may be the cause of misinterpretation, leading the analyst to suppose a 


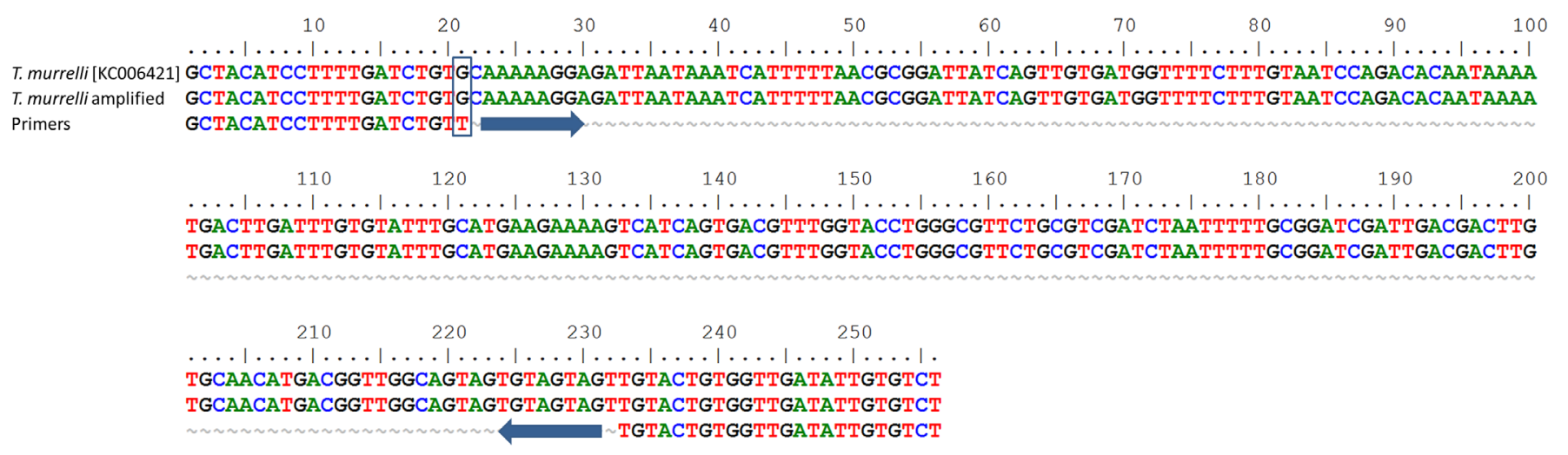

Figure 3. Alignment of the $256 \mathrm{bp}$ fragment of ITS1 II of Trichinella murrelli obtained by uniplex PCR.BLAST analysis revealed 99.6\% identity with different clones of T. murrelli, including clone 5 (Accession number KC006421).

T. murrelli/T. britovi hybrid or cross DNA contamination of the purified DNA sample under analysis. Incorrect identification of T. murrelli larvae occurred in 2016 during the proficiency testing organized by the EURLP for the NRLs to identify Trichinella larvae at the species level. Seven $(33 \%)$ of the 21 participating laboratories failed to identify T.murrelli by multiplex PCR due to the appearance of the unexpected band of $256 \mathrm{bp}$ (Final Report PT-Tm 1/2016; www.iss.it/dinary/crlp/cont/ Final_report_PT_Tm_2016.pdf).

The appearance of the extra band of $256 \mathrm{bp}$ in T. murrelli was previously documented [18], but since this band was generated intermittently, it was not considered diagnostic of T. murrelli and was consequently ignored.

Acknowledgements. Funding was provided in part by DG SANTE of the European Commission in the years 2016-2017.

\section{Conflict of interest}

The authors declare that they have no conflict of interest.

\section{References}

1. Ancelle T, Dupouy-Camet J, Bougnoux ME, Fourestie V, Petit H, Mougeot G, Nozais JP, Lapierre J. 1988. Two outbreaks of trichinosis caused by horse meat in France in 1985. American Journal of Epidemiology, 127 (6), 1302-1311.

2. Codex Alimentarius. 2015. Guidelines for the control of Trichinella spp. in meat of suidae. CAC/GL 86-2015.

3. Commission implementing regulation (EU) 2015/1375. 2015. Laying down specific rules on official controls for Trichinella meat. Official Journal of the European Union.

4. Dubey JP, Hill DE, Zarlenga DS, A. 2006. Trichinella murrelli infection in a domestic dog in the United States. Veterinary Parasitology, 137(3-4), 374-378.

5. Dupouy-Camet J, Robert F, Guillou JP, Vallet C, Perret C, Soulé C. 1994. Identification of Trichinella isolates with random amplified polymorphic DNA markers. Parasitology Research, 80(4), 358-360.
6. EFSA, 2016. The European Union summary report on trends and sources of zoonoses, zoonotic agents and foodborne outbreaks in 2015. EFSA Journal, 14, 4634.

7. Gajadhar AA, Forbes LB. 2010. A 10-year wildlife survey of 15 species of Canadian carnivores identifies new hosts or geographic locations for Trichinella genotypes T2, T4, T5, and T6. Veterinary Parasitology, 168(1-2), 78-83.

8. Gottstein B, Pozio E, Nöckler K. 2009. Epidemiology, diagnosis, treatment, and control of trichinellosis. Clinical Microbiology Reviews, 22, 127-45.

9. Hall RL, Lindsay A, Hammond C, Montgomery SP, Wilkins PP, da Silva AJ, McAuliffe I, de Almeida M, Bishop H, Mathison B, Sun B, Largusa R, Jones JL. 2012. Outbreak of human trichinellosis in Northern California caused by Trichinella murrelli. American Journal of Tropical Medecine and Hygiene, 87(2), 297-302.

10. Hill DE, Samuel MD, Nolden CA, Sundar N, Zarlenga DS, Dubey JP. 2008. Trichinella murrelli in scavenging mammals from south-central Wisconsin, USA. Journal of Wildlife Diseases, 44(3), 629635.

11. International Commission on Trichinellosis, http://www. trichinellosis.org/

12. Korhonen PK, Pozio E, La Rosa G, Chang BC, Koehler AV, Hoberg EP, Boag PR, Tan P, Jex AR, Hofmann A, Sternberg PW, Young ND, Gasser RB. 2016. Phylogenomic and biogeographic reconstruction of the Trichinella complex. Nature Communications, 1(7), 10513.

13. Krivokapich SJ, Pozio E, Gatti GM, Prous CL, Ribicich M, Marucci G, La Rosa G, Confalonieri V. 2012. Trichinella patagoniensis n. sp. (Nematoda), a new encapsulated species infecting carnivorous mammals in South America. International Journal for Parasitology, 42(10), 903-10

14. La Rosa G, Pozio E, Rossi P, Murrell KD. 1992. Allozyme analysis of Trichinella isolates from various host species and geographical regions. Journal of Parasitology, 78, 641-6.

15. Murrell KD, Pozio E. 2011. Worldwide occurrence and impact of human trichinellosis, 1986-2009. Emerging Infectious Diseases, 17, 2194-202.

16. Nöckler, K, Kapel CMO. 2007. Detection and surveillance for Trichinella: meat inspection and hygiene, and legislation, in $\mathrm{FAO} / \mathrm{WHO} / \mathrm{OIE}$ guidelines for the surveillance, management, prevention and control of trichinelloses, J. Dupouy-Camet, K. D. Murrell, Editors, World Organisation for Animal Health Press, Paris, France. p. 69-97.

17. Pozio E, La Rosa G. 2000. Trichinella murrelli n. sp: etiological agent of sylvatic trichinellosis in temperate areas of North America. Journal of Parasitology, 86(1), $134-139$ 
18. Pozio E, Pence DB, La Rosa G, Casulli A, Henke SE. 2001. Trichinella infection in wildlife of the southwestern United States. Journal of Parasitology, 87(5), 1208-1210.

19. Pozio E, Hoberg E, La Rosa G, Zarlenga DS. 2009. Molecular taxonomy, phylogeny and biogeography of nematodes belonging to the Trichinella genus. Infection, Genetics and Evolution, 9(4), 606-616.

20. Pozio E, La Rosa G. 2010. Trichinella, in Molecular Detection of Foodborne Pathogens, Liu, D, Editors. CRC Press, Taylor \& Francis Group, Boca Raton. p. 851-863.

21. Pozio, E,Zarlenga, DS. 2013. New pieces of the Trichinella puzzle. International Journal for Parasitology, 43, 983-997.
22. Reichard MV, Tiernan KE, Paras KL, Interisano M, Reiskind MH, Panciera RJ, Pozio E. 2011. Detection of Trichinella murrelli in coyotes (Canis latrans) from Oklahoma and North Texas. Veterinary Parasitology, 182 (2-4), 368-371.

23. World Organisation for Animal Health. 2017. Chapter 2.1.20 Trichinellosis, in Manual of Diagnostic Tests and Vaccines for Terrestrial Animals. p. 1-11.

24. Zarlenga DS, Chute MB, Martin A, Kapel CM. 1999. A multiplex PCR for unequivocal differentiation of all encapsulated and non-encapsulated genotypes of Trichinella. International Journal for Parasitology, 29(11), 1859-1867.

Cite this article as: Karadjian G, Heckmann A, Rosa GL, Pozio E, Boireau P, Vallée I. 2017. Molecular identification of Trichinella species by multiplex PCR: new insight for Trichinella murrelli. Parasite 24, 52

\section{O PARASTE}

An international open-access, peer-reviewed, online journal publishing high quality papers on all aspects of human and animal parasitology

Reviews, articles and short notes may be submitted. Fields include, but are not limited to: general, medical and veterinary parasitology; morphology, including ultrastructure; parasite systematics, including entomology, acarology, helminthology and protistology, and molecular analyses; molecular biology and biochemistry; immunology of parasitic diseases; host-parasite relationships; ecology and life history of parasites; epidemiology; therapeutics; new diagnostic tools.

All papers in Parasite are published in English. Manuscripts should have a broad interest and must not have been published or submitted elsewhere. No limit is imposed on the length of manuscripts.

Parasite (open-access) continues Parasite (print and online editions, 1994-2012) and Annales de Parasitologie Humaine et Comparée (1923-1993) and is the official journal of the Société Française de Parasitologie. 